\title{
Circularity in value chains for building materials
}

\author{
Evert-Jan Velzing', Annemiek van der Meijden', Kitty Vreeswijk¹, Ruben Vrijhoef ${ }^{1}$ \\ ${ }^{1}$ Research Centre for Healthy and Sustainable Living, University of Applied Sciences \\ Utrecht, The Netherlands.
}

\begin{abstract}
The urgency for developing a circular economy is growing, and more and more companies and organisations are concerned with the importance of adapting their business to fit a changing economy. However, many analyses on the circular economy are still rather abstract and there is a lack of understanding about what circularity would mean for specific industries. This insufficient insight especially seems to be apparent in the building and construction sector. Besides, the building and construction sector is responsible for a major part of energy use and emissions.

To tackle the issue of insufficient insight into the business consequences of circular devlopments, further research is necessary. Therefore, we propose to collaborate on a research project that aims to provide a more detailed level of analysis. The goal is to identify drivers and barriers to make better use of materials in the building and construction sector. This further research would benefit from an international collaboration between universities of applied sciences and industry from different European countries. An additional benefit of the applied orientation would be the relevance for professional education programmes.
\end{abstract}

Keywords: Circular economy; circular strategy; building materials; value chain cooperation; circular business models. 


\section{Introduction}

There is common understanding about the necessity for a transition to a circular economy (e.g. EC, 2015; UNCTAD, 2018; Mazzucato, 2018). However, many analysis and (policy) discussion about the transition to a circular economy take place on a macroeconomic level (e.g. Stahel, 2016; Ghisellini et al, 2016; Kirchherr et al, 2018). This makes terms such as 'closing the loop' and circularity catch-all terms, that do little to help businesses involved. Therefore, we argue that a more detailed level of analysis is needed in order to identify barriers that hold back the transition to a circular economy.

Because of their central role in consuming goods (UN, 2018) and energy (Chuchí et al, 2014) we focus on the building and construction sector. For instance, the Dutch building and construction sector is responsible for 50 percent of the resource use, 40 percent of the total energy use, 35 percent of the $\mathrm{CO}_{2}$ emissions, and 30 percent from the total water usage (Nederland Circulair in 2050, 2016) . Moreover, around 40 percent of all Dutch waste is related to building or demolition work (CE, 2014; CBS et al, 2017). It is safe to assume that the scale of these figures are similar in other European countries.

Therefore, the building and construction sector can be seen as an important actor in actualizing the European Commisson's Circular Economy Action Plan. With this plan the European Commission aims to speed up the transformation of European industries to a circular economy and thereby make European company fit for the future (EC, 2015; EC, 2019).

\section{The situation in the (circular) building economy}

In the quest to reach more sustainable development in the building economy, it is important to use resources more efficiently, and to make the built environment more circular. One way to contribute to this, is to use building materials in a circular way. This means to reuse demolition materials - materials that stem from buildings that are being refurbished or torn down. A lot of such materials are already available, and in the Netherlands there is already quite a demand for this, due to government policies.

However, supply and demand are not yet connected. There are several obstacles still hindering this. For example, demolition material is often quite old and does not fit current technical requirements. Even when it fits these requirements, it is not easy to integrate them into current building process, as these are often based on a software that needs a lot of technical information about the materials, which is not always readily available for used materials. Moreover, demolition materials often become accessible in moments that they are not yet needed in other building projects. 
To reduce these obstacles, the transition to a circular building sector requires new ways to collaborate, new processes, and new business models.

\section{Questions that arise}

In sum, there is need for more knowledge about and insight into the value chains within the building and construction sector. Only then, it would be feasible to develop the companies so they are fit for a ciruclair building economy. To gain more knowledge on this subject, we focus on the use of materials in the building and construction sector, and we propose to start up a research project that aims to answer the following research question:

What are the drivers and barriers to make better (re-)use of building and construction materials?

In general both social and technical barriers will hamper the transition to a circular (building) economy (De Jesus \& Mendonça, 2018). In order to better understand these barriers for specific materials in the building sector, we propose analyses that take different perspectives, such as: technical analysis of requirements and feasible circular strategies, research on valuechain cooperation and/or circular (eco)systems, and analysis of circular business models.

This can lead to the following research sub-questions:

- Which materials become available during refurbishing/demolishen processes? And how many?

- What circular strategies can be used to make better use of materials?

- What are the requirements for reusing them?

- How can a sector of industry organize their value chain to facilitate viable circular strategies? What are the consequences for cooperation between actors involved?

- What business models support circular use of building materials?

- What circular business models can be proposed that support the reuse of demolishen materials? 


\section{Approach}

Because of the major role of the building and construction sector in energy and material use and the international dependence of value chains involved, it is beneficial to gather insight from different European countries. Therefore, we propose to set up an international collaboration of research insitutes and industry partners. The urgency of the matter and the call for better understanding and even solutions, are arguments to take on an applied research approach. This means that we aim to execute detailed level analyses in existing value chains for both best practices and less performing examples.

We propose to base the analysis on case studies on existing building materials, such as concrete, bricks and synthetic building materials, and their actual value chains. We can use desk research based on both scientific and grey literature and in-depth interviews to answer the research questions mentioned above.

In order to be able to set up this research we seek to combine different specialisations. As a practice oriented research institute, HU University of Applied Sciences aims to transfer knowledge and to develop skills that are relevant for professional practice. This means that researchers from our institute have experience with practical oriented research projects, where companies are involved. The research group involved has wide experience in the construction sector and sustainable and circular urban area development. More specific, our expertise lies in circular business models, ecosystem or network creation, and assessing sustainable policy making.To form our collaboration we seek partners that have a knowledge base in the (circular) building economy and/or indsutries that produce materials being used in the building and construstion sector. Besides, we look for parnters with good relations with companies, so case studies in several countries can be done, and a mulit-case study project can be formed within different cultural contexts. 


\section{References}

CBS, PBL \& Wageningen UR. (2017). Vrijkomen en verwerking van afval per doelgroep, 1990-2014 (indicator 0206, versie 13, 26 janauri2017). Retrieved from: https://www.clo.nl/indicatoren/nl0206-vrijkomen-en-verwerking-van-afval-perdoelgroep

Cuchí, A.; Arcas, J.; Casals, M. \& Fobella, G. (2014). Building a common home Building sector - A global vision report. Produced by the Global Vision Area within the World SB14 Barcelona Conference.

De Jesus, A. \& Mendonça, S. (2018). Lost in Transition? Drivers and Barriers in the Ecoinnovation Road to the Circular Economy. Ecological Economics, 145, 75-89. doi: 10.1016/j.ecolecon.2017.08.001.

EC. (2015). Closing the Loop - An EU action plan for the Circular Economy. Brussels: European Commission.

EC. (2019). Report from the Commission to the European Parliament, the Council, the European Economic and Social Committee and the Committee of the Regions on the implementation of the Circualr Economy Action Plan. Brussels: European Commission.

Ghisellini, P; Cialini, C. \& Ulgiati, S. (2016). A review on circular economy: the expected transition to a balanced interplay of environmental and economic systems. Journal of Cleaner Production, 114, 11-32. doi: 10.1016/j.jclepro.2015.09.007.

Kirchherr, J., Pisciceli, L., Bour, R., Kostense-Smit, E., Muller, J., Huibrechtse-Truijens, A. \& Hekkert, M. (2018). Barriers to the Circular Economy: Evidence From the European Union (EU). Ecological Economics, 150, 264-272.

Mazzucato, M. (2018). Mission-Oriented Research \& Innovation in the European Union - A problem-solving approach to fuel innovation-led growth. Retrieved from: European Commission; https://ec.europa.eu/info/sites/info/files/mazzucato_report_2018.pdf

Nederland circulair in 2050. Rijksbreed programma Circulaire Economie (2016). Den Haag: Ministerie van Infrastructuur en Milieu \& Ministerie van Economische Zaken.

Stahel, W.R. (2016) The Circular Economy. Nature, 531(7595), 435-438.

UN. (2018). 2018 Global Status Report - Towards a zero-emission, efficient and resilient buildings and construction sector. United Nations Environment Programme.

UNCTAD. (2018). Circular Economy: The New Normal (Policy Brief No. 61). Retrieved from United Nations Conference on Trade and Development (UNCTAD): https://unctad.org/en/PublicationsLibrary/presspb2017d10_en.pdf 